Hashimoto K. Ultrastructure of the human toenail. Part I. Proximal nail matrix. J Invest Dermatol 1971; 56:235-46.

Issa MM, Tanner WA. Approach to ingrowing toenails: the wedge resection/segmental phenolization combination treatment. Br J Surg $1988 ; 75: 181-3$

Lewin K. The normal finger nail. Br J Dermatol 1965; 77:421-30.

Morkane AJ, Robertson RW, Inglis GS. Segmental phenolization of ingrowing toenails: a randomized controlled study. Br J Surg 1984; $71: 526-7$
Pettine KA, Cofield RH, Johnson KA, Bussey RM. Ingrown toenail: results of surgical treatment. Foot Ankle 1988; 9:130-4.

Townsend AC, Scott PJ. Ingrowing toenail and onychogryphosis. J Bone Joint Surg [Br] 1966; 48-B:354-8.

Wallace WA, Milne DD, Andrew T. Gutter treatment for ingrowing toenails. Br Med J 1979;ii:168-71.

\title{
A SIMPLE METHOD FOR REMOVAL OF A FRACTURED INTRAMEDULLARY NAIL
}

OFER LEVY, YEHUDA AMIT, STEVEN VELKES, HENRI HOROSZOWSKI

Fatigue failure of an intramedullary nail may occur if there is delayed or nonunion of the fracture (Zimmerman and Klasen 1983; Winquist, Hansen and Clawson 1984; Bucholz, Ross and Lawrence 1987) and the distal end of the fractured nail is then difficult to remove. Several methods have been described (Böhler 1968; Yoslow and LaMont 1986; Mooney, Chabon and Poehling 1991) to which we add a simple and reliable technique.

Patients. From 1986 to 1991 we treated five patients with fractured femoral intramedullary nails, all associated with painful delayed union or nonunion. Four nails were of the locking type and one was a Küntscher pattern. They had been in place for one to four years.

Technique. The operation is performed with the patient on a fracture table with image-intensifier control. The intramedullary canal is opened at the greater trochanter (Taylor 1992) and any locking screws are removed. The proximal part of the nail is removed and a nail which is $1 \mathrm{~mm}$ smaller in diameter than the fractured nail is passed down the intramedullary canal and gently impacted into the opening of the distal nail fragment. Both nails are then removed (Fig. 1). If there is delayed or nonunion the intramedullary canal is then reamed and a nail of larger diameter is inserted.

Results. In all five cases the removal of the distal nail fragment was easy and uneventful with no difficulties during extraction. The average time taken was ten minutes (7 to 15).

O. Levy, MD, Senior Resident in Orthopaedics

Y. Amit, MD, Senior Orthopaedic Surgeon

S. Velkes, MD, Senior Orthopaedic Surgeon

H. Horoszowski, MD, Professor and Chairman of Orthopaedic Surgery

Department of Orthopaedic Surgery, The Chaim Sheba Medical Center

Tel-Hashomer and Sackler School of Medicine, Tel Aviv University, Israel.

Correspondence to Dr O. Levy.

(C)1994 British Editorial Society of Bone and Joint Surgery 0301-620X/94/3R98 \$2.00

J Bone Joint Surg [Br] 1994; 76-B:502.

Received 13 May 1993; Accepted 29 June 1993

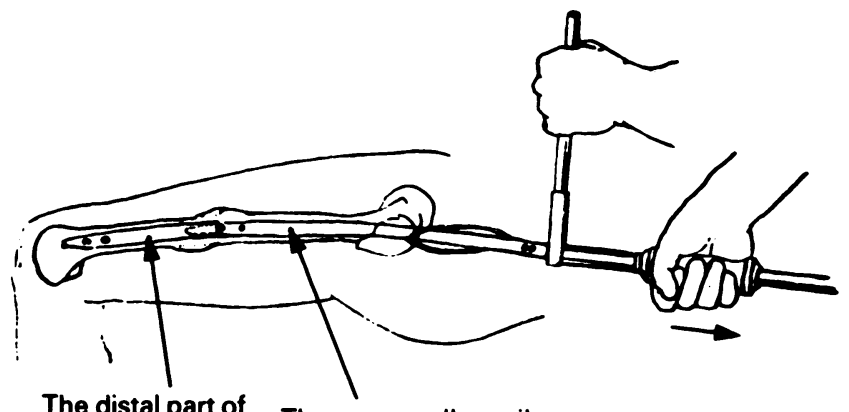

The distal part of
the fractured nail

The new smaller nail

Fig. 1

Discussion. An intramedullary nail imparts stability only for a limited period of time until bone healing is attained. During this period there is a race between bone healing and fatigue failure of the implant and fractured nails will continue to be seen. Our method of removal is simple, reliable and safe and requires no special equipment. It could also be used in the tibia and the humerus.

No benefits in any form have been received or will be received from a commercial party related directly or indirectly to the subject of this article.

\section{REFERENCES}

Böhler J. Closed intramedullary nailing of the femur. Clin Orthop 1968; 60:51-67.

Bucholz RW, Ross SE, Lawrence KL. Fatigue fracture of the interlocking nail in the treatment of fractures of the distal part of the femoral shaft. J Bone Joint Surg [Am] 1987; 69-A:1391-9.

Mooney J, Chabon SJ, Poehling GG. Removal of a fractured intramedullary nail. Orthop Rev 1991; 20:923-4.

Taylor JC. Fractures of lower extremity. In: Crenshaw AH, ed. Campbell's operative orthopaedics. Eighth ed, Vol. 2. St Louis, etc: CV Mosby, 1992:785-873.

Winquist RA, Hansen ST Jr, Clawson DK. Closed intramedullary nailing of femoral fractures: a report of five hundred and twenty cases. J Bone Joint Surg [Am] 1984; 66-A:529-39.

Yoslow W, LaMont JG. Alternative method for removing an impacted AO intramedullary nail. Clin Orthop 1986; 202:237-8.

Zimmerman KW, Klasen HJ. Mechanical failure of intramedullary nails after fracture union. J Bone Joint Surg [Br] 1983; 65-B:274-5. 